Г. Т. Терешкевич (с. Аіогена),

к. держ. упр., дочент, дочент кафедри філософії та економіки,

Аьвівський начіональний медичний університет імені Аанила Галищького,

докторант кафедри парламентаризму та політичного менеджменту, Начіональна академія

державного управління при Президентові України

ORCID ID: 0000-0003-4427-7872

DOI: $10.32702 / 2306-6814.2020 .2 .104$

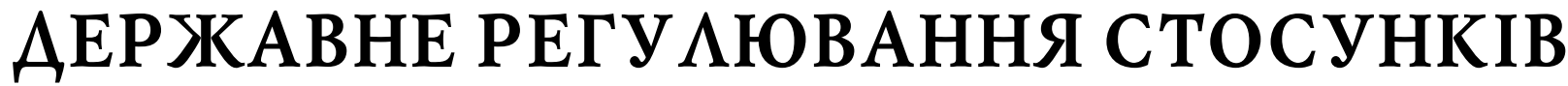 МІЖАЕРઝАВОЮ ТА ЦЕРКВОЮ
}

\author{
H. Tereshkevych (s. Diogena), \\ $\mathrm{PhD}$ in Public Administration, \\ Associate Professor of the Department of Philosophy and Economy, \\ Danylo Halytsky Lviv National Medical University \\ Doctorate in the Department of Parliamentarism and Political Management, \\ National Academy for Public Administration under the President of Ukraine
}

\section{STATE REGULATION OF RELATIONS BETWEEN STATE AND CHURCH}

\begin{abstract}
Становлення держави можливе передусім через духовне оновлення нації. Публічним управлінцям необхідно подбати про відповідну нормативну базу для поглиблення взаємин церкви і держави та їх якісної взаємодоповнюючої співпраці.

Відсутнє комплексне наукове дослідження, яке розкрило б необхідність залучення церкви до державотворчих процесів.

Метою публікації є науково-теоретичне обгрунтування необхідності визнання державою Церкви як незалежного, самостійного та морального авторитета суспільства на законодавчому рівні.

Історично доведено, що церква структурує духовний світ людини, а держава на законодавчому рівні створює умови для її всебічного розвитку та громадянского зросту.

Пропоноване дослідження ставить завдання перед публічними управлінцями створити правове поле для надання можливості громадянам України реалізувати християнські потреби 3 допомогою Церкви і держави.
\end{abstract}

Перспективи подальших досліджень полягають у розробці механізмів впровадження християнських морально-етичних цінностей у процеси державотворення.

Formation of the problem. Ukraine has lost its communist regime, but the struggle against the post-Soviet stereotype of thinking among individual citizens born in the former Soviet Union is still ongoing. Public leaders need to have unwavering spiritual orientations in order to be able to change the country positively. This justifies the need to deepen the relationship between the Church and the state and their qualitative complementary cooperation. The state regulation of these relations rests with the public authorities, which are supposed to provide their legal framework.

Research Analysis. There is still no comprehensive scientific study that would reveal the nature of the relationship between the state and the church, especially at the present stage, and the need to involve the church in state-building processes.

The aim of the publication is to provide a scientific and theoretical substantiation of the need for the state to recognize the Church as an independent and independent partner and moral authority of the society at the legislative level. 
Statement of the main part. The proposed study aims to create a legal framework for public administrators to enable Ukrainian citizens to fulfill Christian needs with the help of the Church and the state.

Conclusions. The wording of the current Article 1 of the Constitution of Ukraine should be supplemented by public administrators, adding to the definition of the State of Ukraine as Christian; and to amend Article 35 of the Constitution of Ukraine as amended: "The church (s) and the state in Ukraine are public, independent, independent institutions that, together, each in their own way and purpose, care for the welfare of their faithful and citizens. Appropriate agreements can be made between the state and the church. Relations between the state and the Church are based on partnership, mutual assistance, mutual respect and tolerance. The state designates the Church as a subject of legal relations with a special social status, which is determined by the legislation of Ukraine or the treaty. The state does not prevent the introduction of religious sciences on a voluntary basis at the school. The church is a spiritual and moral authority in society.

Prospectives for further research are to develop mechanisms for the introduction of Christian moral and ethical values in the processes of state formation.

КлючоВі слоВа: держаВа, ЦеркВа, церковно-держаВністосунки, християнськіморально-етичні цінності ізасади, Конституиія України.

Key words: state, church, church-state relations, Christian moral and ethical values and principles, Constitution of Ukraine.

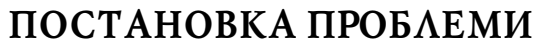

\section{У ЗАГААЬНОМУ ВИГАЯАІ ТА ЇЇ ЗВ'ЯЗОК ІЗ ВАЖАИВИМИ НАУКОВИМИ ЧИ ПРАКТИЧНИМИ ЗАВААННЯМИ}

Становлення держави можливе передусім через духовне оновлення нації. Упродовж століть українське суспільство зберігало свій духовний потенціал завдяки вірі, носіями якої були звичайні люди, насамперед селяни. Упродовж століть побожність була тим благодатним грунтом, на якому формувалася висока мораль та здорова життєва фрілософрія українців.

Багатовікова колонізація та окупація України, Жовтневий переворот, низка інших трагічних подій XX ст. (жорстокі придушення селянських повстань, штучний голодомор, втрати у другій світовій війні, політичні репресії, боротьба з патріотами, радянський, тоталітарний, імперський, атеїстичний, комуністичний режим) спричинили занепад суспільства.

3 набуттям Україною Незалежності з особливою актуальністю постала проблема духовного оновлення, відродження народу. Адже пропаганда комуністичної ідеології та заборона релігії в радянські часи призвела до того, що частина громадян колишнього СРСР, зомбована засобами масової інформації, щиро вірила в комуністичну партію таїї ідеали, не уявляючи свого існування поза межами цього державного устрою. Україна ж позбулася тоталітарного режиму правління, але боротьба 3 пострадянським стереотипом мислення серед деяких громадян, хто народився в колишньому Радянському Союзі, ще і досі триває. Найкращим соратником у цій боротьбі за вільного від відтисків минулого свідомого громадянина $є$ повернення до духовних джерел, навернення до Бога та переосмислення морально-етичних цінностей і установок, якими живе держава і суспільство.
Церква активно допомагає державі у сорерах духовно-патріотичного виховання підлітків та молоді, веде цілеспрямовану душпастирську роботу там, де в держави є обмежені важелі впливу - із соціально вразливими верствами людей, а саме у пенітенціарних закладах, колоніях для неповнолітніх, у війську та в шпиталях, лікарнях тощо.

Сьогодні в Україні виросло покоління молодих людей (ровесників її незалежності), які для того щоб бути спроможними позитивно змінювати країну, повинні мати непохитні духовні орієнтири. Це обгрунтовує потребу у поглибленні взаємин Церкви і держави та у їх якісній взаємодоповнюючій співпраці. Державне регулювання цих стосунків покладається на органи публічного управління, які б мали забезпечити їх нормативну базу.

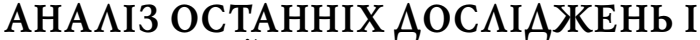
ПУБАІКАЦІЙ, В ЯКИХ ЗАПОЧАТКОВАНО

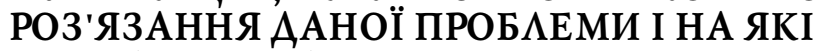
СПИРАЕТЬСЯ АВТОР

В Україні питання регулювання стосунків між державою та Церквою досліджували: М. Білинська, Б. Гавдьо, В. Гошовська, В. Дубічинський, О. Зайчук, Л. Луць, С. Мудрий, Н. Оніщенко, М. Рибачук, С. Сливка, В. Ткаченко, Г. Хорунжій, А. Черній, М. Цвік та інші.

Певну увагу цим проблемам у своїх працях приділили закордонні вчені: Мондін Баттіста, Мартін Де Агар, Ліберо Джероза та інші.

Проте в Україні досі відсутнє комплексне наукове дослідження, що розкрило б природу стосунків держави і церкви, особливо на сучасному етапі, та необхідність залучення церкви до державотворчих процесів. 


\section{ВИАІАЕННЯ НЕ ВИРІШЕНИХ РАНІШЕ

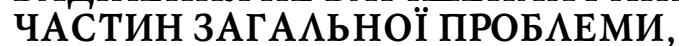 КОТРИМ ПРИСВЯЧУЕТЬСЯ ОЗНАЧЕНА СТАТТЯ}

Європейське співтовариство, яке відкинуло християнство як сполучну основу суспільства, сьогодні потерпає від прийняття псевдоцінностей, що спричиняють психічні розлади в окремих громадян та стають причиною деморалізації суспільства в цілому. Зокрема визнання одностатевих шлюбів призвело до гомодиктатури та деградації багатьох людей, що прикриваючись свободою особистості, насправді руйнують свою психіку, відкидаючи совість та мораль. Не даремно, вперше вірус ВІЛ-СНІДу було виявлено у середовищі гомосексуалістів, які свободою совісті називали розпусту та статеві збочення. Визнання збочень нормою $є$ замахом на трансцендентну гідність людськогожиття, робить людину рабом гріха, вразливою, хворобливою, деморалізованою особою.

Першочерговою необхідністю для публічних управлінців $€$ поновити роль Церкви в якості морально-етичного стрижня нації, визнаючи ії̈ позитивно структуруючий вплив на суспільство. Українська традиція душпастирства - це кропітка праця численних священників, богопосвячених осіб, якібули зразковими знавцями психології, мудрими порадниками та голосом совісті упродовж століть після Хрещення України-Русі. Духівництво було дотичним до виховання кожного громадянина, що загалом позначалося на високому духовному потенціалі народу.

Християнство упродовж двох-тисячолітньої історії відігравало надзвичайно важливу виховну та просвітницьку роль, що однозначно було на користь і суспільству, і державі. 3 позиції християнства Бог є люблячим і милосердним Батьком, людина є Його улюбленим сотворінням, створеним на Його образ і подобу, а світ є об'єктом турботливого Божого Провидіння. Людське існування $€$ частиною історичного проекту спасіння, що через Ісуса Христа, Ключа спасіння, отримує глибокий унітарний характер: Христос - Альра і Омега кожної речі. Пресвята Трійця надає нового сенсу моралі, що має любов до Бога та ближнього як головну заповідь [1, с. 15].

Дві інституції, церква і держава можуть успішно співпрацювати. В засобах масової інформації ми часто бачимо зустрічі ієрархів УПЦ, УГКЦ, РКЦ з Президентом та урядом. Залучення Церкви до процесів державотворення, до виховання свідомого і сумлінного громадянина $\epsilon$ віховим етапом становлення держави. Важливо, щоб держава розглядала релігійні організації та їх представників як ділових партнерів у вирішенні соціальних, міжнародних і глобальних питань. Варто окреслити і напрацювати точки їхнього дотику, вибудувати ієрархію їхнього співвідношення, характер, глибину цих стосунків, щоб отримати користь від взаємної співпраці.

До прийняття християнства в суспільстві не було відмінності між релігійними і соціальними обов'язками, бо релігія була канвою соціально-культурних відносин в державі. Для побудови ефективної моделі стосунків між державою та Церквою органам публічного управління варто вивчити можливі варіанти взаємин між ними.
Обидві інституції - Церква і держава є складними, багатошаровими структурами, цілі яких у головних засадах співпадають. Метою держави є упорядкування відносин між членами суспільства і створення оптимальних умов для онтологічного розвитку кожного з них. Такоюж приблизно єй мета церкви.

Соціально-історична обумовленість державно-церковних стосунків призводить їх до взаємозалежності від історичних та соціальних передумов їхнього існування. Досвід різного співіснування держави і церкви довів, що найкращим вирішенням питання стосунків для цих інституцій $є$ співпраця у реалізації спільних стратегічних духовних цінностей та розкриття покликання кожного громадянина. Відрізняло ці дві інституції те, що церква завжди була позачасовою структурою, в той час як держава $є$ узалежнена від культурно-історичного розвитку суспільства та інших чинників. Втім, діаметральна протилежність цих установ, їхня різнобічність та складність стосунків пояснюється різними цілями та методами, якими вони впливають на свою аудиторію. Тут точкою дотику є правильне розуміння людини, її аксіологічного виміру, що фрормує правильну модель суспільства, де гармонійно взаємодіють церква і держава. Коли ж, навпаки, розуміння людини є спотвореним, тоді створюється модель держави, де дії церкви і держави йдуть врозріз із аксіологічною сутністю людини та середовищем її існування.

Втім, на біоетику, яка співзвучна з християнським ученням про людину, її гідність та неповторну цінність (і грунтується на відповідальності людської особи за власне існування та всі живі істоти у світі і за весь світ загалом), покладається роль бути основоположним зв'язковим елементом між державою і церквою у державотворчих процесах, враховуючи її потужний виховний вплив на суспільство. Особливо важливо запровадити її в систему підготовки, перепідготовки та підвищення кваліфікації публічних службовців, тому що для держави $є$ вкрай вагомим духовний та морально-етичний статус її громадян (чим вищий рівень духовності та моральності держави і суспільства - тим більше порядку і безпеки в них).

Держава та церква мають координувати спільні дії, зважаючи на соціокультурний, політико-економічний та трансцендентно-метафрізичний простір.

Україні треба відкинути науковий атеїзм та все державотворення, яке базувалося на цьому лжевченні і задіяти капітал, яким володіє Церква. Від якості взаємозв'язків держави та Церкви справді залежить успішний розвиток нової України, ії духовності, формування нової генерації, спроможної будувати сучасну державу. Слід використати шанс інтелектуальної, богословської та організаційної сили Церкви у стосунках з державою.

На сучасному етапі цих взаємин ми спостерігаємо ситуацію, коли стосунки між церквою і державою розвиваються в напряму взаємодії. Поступово з'являється розуміння, що опираючись на церкву як на важливу складову забезпечення духовного розвитку своїх громадян, Україна має шанси швидше подолати негативні наслідки у всіх сорерах суспільного життя. Адже високий рівень духовності тотожний новим можливостям, як це можна простежити в переважно християнських країHax. 


\section{META CTATTI}

Метою публікації $€$ науково-теоретичне обгрунтування необхідності визнання державою Церкви як незалежного та самостійного партнера і морального авторитета суспільства на законодавчому рівні.

\section{ВИК ААА ОСНОВНОГО МАТЕРІААУ АОС АІАЖЕННЯ 3 ПОВНИМ ОБГРУНТУВАННЯМ НАУКОВИХ ОТРИМАНИХ РЕЗУ $А$ ТАТІВ}

Стосунки держави та церкви упродовж тисячоліть перейшли різні фрази дотичності (від абсолютної влади церкви, як було за цезаропапізму і до повного заперечення церкви, як було в атеїстичних країнах) та співпраці, врегульовуючи відносини з громадянами. Втім, час показав, що найкращим взірцем такої співпраці $є$ модель, коли церква структурує духовний світ сучасника, а держава створює умови для його всебічного розвитку та громадянського зросту. За своєю суттю, стосунки між цими інституціями в ідеалі мали б доповнювати одна одну і взаємодіяти, враховуючи той чинник, що кожна 3 цих інституцій покликана працювати на благо людини лише з тією різницею, що церква орієнтована на вічні і незмінні цінності, водночас як держава узалежнена від історичних епох, подій, лідерів тощо.

Коли держава належним чином піклується про громадян, дотримання їхніх прав та свобод, тоді кожен індивід має рівні умови для розвитку, відтак загалом суспільство своїми солідарними діями може впливати на покращення соціального порядку. Водночас Церква виховує особистість, наповнює її життя повнотою, що опосередковано і безпосередньо впливає на якість іiі зв'язків зі світом - з родиною, з колективом, з суспільством.

Відтак Церкву та її вплив на спільноту варто віднести до ссрери національних пріоритетів як один із основних чинників оздоровлення нації, її гармонійного та позитивного налаштування. Держава не може охопити настільки детально усі прошарки суспільства, однак це під силу священникам, які покликані скеровувати та навертати до духовних цінностей та орієнтирів, внаслідок чого гармонізуються всі сфери життя. Саме такий симбіоз $є$ запорукою фрормування здорового суспільства, літаком, який опирається в леті на два крила - Державу і Церкву. Таке порівняння свідчить про те, що як літак не може літати з одним крилом, так і людині потрібні держава для захисту його як громадянина та Церква для реалізації метафізичних прагнень його душі.

Неузгодженість законів цивільних із законами Божими чи природними лежить в основі тліючого конфлікту між церквою та державою в Україні, що має негативний вплив на суспільство. Народ, який дозволяє вбивати своїх ненароджених дітей, приречений на знищення. На органи публічного управління покладається завдання вирішити цю дилему на користь збереження духовного здоров'я нації та недоторканості людського життя.

Проте, незалежно від того, усі сорери життєдіяльності людини захищені чи ні - кожній людській особі присутня беззаперечна гідність та дарована їй Господом свобода. Ця свобода зовсім не $є$ вседозволенністю, навпаки вона $€$ усвідомленням величі вінця Господньо- го творіння - Людини. В цьому ключі людське життя $€$ трансцендентним шляхом, що починається з моменту запліднення та виходить за межі фрізичного життя.

Судочинство та вся сорера публічного управління користуються визначенням, згідно з яким людське життя захищається з моменту народження та триває до смерті. Ця законодавча помилка спричинює порушення прав людини, яка знаходиться в стані внутрішньоутробного розвитку, зокрема спричиняє численні етично-неприпустимі дії, які стосуються її життя. Для забезпечення поваги до гідності людини в соціумі необхідно, щоб на законодавчому рівні були прийняті закони, що відповідають вимогам біоетики.

Успішними та позитивними в історії України були періоди, коли до влади приходили керманичі, що стояли на засадах християнства. Традиційно українці мали б прагнути до гармонійного сприйняття світу крізь призму високої духовності та морально-етичних стандартів. До цього спонукує глибока віра, слідування за християнськими цінностями та ідеалами, а також притаманна кожній людині гідність.

За сприянням держави у 2018 році українська православна церква отримала Томос від Вселенського патріарха ( 15 грудня 2018 р. Синодом Вселенського Патріархату було прийнято рішення про початок процедур, необхідних для надання Томосу про автокефалію Православної Церкви в Україні, а 6 січня 2019 р. патріарх Варфоломій вручив Томос про автокефалію Православної Церкви України митрополиту Київському і всієї України Епіфанію [2], що, по суті, є визнанням незалежності нашої держави в ширшому розумінні. 3 огляду на ці події є надія, що надалі стосунки між церквою і державою будуть поглиблюватися на користь усіх.

Правова держава враховує тільки загальне внутрішнє благо громадян, тоді як християнська правова держава - це законна, справедлива держава, яка служить людям, а не самій собі і підпорядковує загальне благо абсолютному Благу, тобто Богові, оскільки людина є єдністю духа, душі і тіла. Людина як особа перетинає кордони часу і простору та призначена до вічного життя, тоді як існування держави обмежене в часі та просторі. 3 позиції християнства держава $€$ важливим, фундаментальним інструментом для життя людини в цьому світі і її фрункції мали б бути спрямованими на абсолютне благо найвищої на Землі цінності, якою $€$ людська особа. Ціллю держави є сприяти реалізації людини на її благо та благо всієї людської спільноти [3, 51-52; 4, п. 76].

Будуючи демократичне та громадянське суспільство, Україна приєдналася до основоположних міжнародних угод з питань захисту прав та свобод людини. Проте в нашому суспільстві все ще $є$ проблеми, пов'язані із забезпеченням органами публічного управління свободи совісті, що є одним із наслідків не пізнання Бога та Церкви в своїй сутності значною частиною громадян України. Адже відбулася підміна понять, що спричинила поширення зневіри та атеїзму. Непорозуміння, які точилися між державою та Церквою впродовж історії, свідчать про необхідність пошуку нових підходів для розв'язання спірних питань. I хоча відповідь на ці запити існує давно, бар'єром є тільки людська хибна недовіра до можливостей та повноважень Господа. 
Поняття Творця для кожної людини є індивідуальним, однак $є$ спільні засади, дотримуючись яких, можемо збудувати справедливу та цивілізовану державу на грунті християнської моралі. Господь має бути не об'єктом фанатизму чи результатом людської фантазії, а реальним Помічником, добрим Другом, Спасителем. Таке розуміння позитивно налаштовує психіку людини, допомагає їй зважено та об'єктивно приймати рішення будь-якого рівня складності.

Сьогодні вже не досить переживати внутрішньо власну віру як результат особистого навернення, але треба виявляти її як зусилля соціальної чи політичної діяльності, усвідомлюючи невідкладність проблем, які потребують вирішення, як свідчення справжнього бажання оновити світ відповідно до християнського ідеалу. Така модель "культурного посередництва" християнина між церквою і державою $є$ еталоном гармонії політичної дії та віри [5, с. $226-227]$.

Для громадянина $є$ вкрай важливим відповідно до вимог свого світогляду та виховання мати можливість обирати релігію. Подбати про це має держава та церква, адже це входить до їхніх функцій. До переліку їхніх повноважень і їхнім прямим обов'язком є створення нормативно-правового поля, а саме церковних статутів, держаних законів та інших приписів, які будуть регламентувати здійснення вибору релігії та її сповідування. Одним із показників, що демонструє ступінь втілення в життя засад свободи совісті, $є$ власне можливість розвиватися, вільно обирати собі конфесію. Так і повинен втілюватися в життя основоположний принцип свободи, який людині дарований Богом і у відповідності до того, що людина $є$ створеною на образ і подобу Божу. Варто зазначити, що суспільство має ті ж ознаки, які притаманні людині, тільки у більш узагальнених рисах. Першою країною, яка проголосила ці засади нормою, стали Сполучені Штати Америки, які свій стрімкий економічний розвиток і успіх пов'язують 3 прямим наслідком свобод, проголошених і гарантованих їхньою конституцією, що є одним із фракторів розвитку суспільства і держави. Саме людина зі своїм світом та потребами є тим мікрокосмосом, трансцендентність якої лежить в основі будь-якого суспільного явища. Кожна особа в державі є елементом, який пов'язаний у той чи інший спосіб із усіма решта членами суспільства. Тому головуючим фрактором $є$ якість відносин у соціумі. Бог творить суспільство через людину, закладаючи в неї основи суспільності. Його заповіді стосуються кожного і усіх одночасно. Такий антропологічно-суспільний підхід дає можливість поглянути на людину, як об'єкт, в якому криються основні причини та проблеми суспільних негараздів. Взаємодія особи із соціумом випливає із самої сутності людини, точніше з її природних потреб бути в товаристві, бути суспільно корисною, суспільно захищеною. Суспільність $€$ тим містком, який дозволяє кожній людині діяти за власною волею, але узгоджувати свої дії із суспільним запитом, культурою, потребами. В цьому контексті релігія постає засобом залучення індивіда до різних сорер суспільного життя. Стосунки людини з Богом трансфрормуються на стосунки людини з людиною, стаючи подібними до Божих, відтак суттєво якіснішими.
Відтак від здорових стосунків держави і Церкви залежить здоров'я суспільства, моральний клімат у ньому. Відносини між цими суб'єктами набули сталих фрорм та $€$ класифіковані науковцями.

Розглянемо систематизацію типів взаємин між Церквою та державою, розроблену вченим-релігієзнавцем А.М. Чернієм, який, у відповідності до міри впливу цих інституцій одна на одну, виокремив такі моделі державно-церковних взаємин [6, с. 268]:

1. Теократія (гр. theos - Бог, kratos - влада) вся повнота влади в державі належить главі панівної церкви таїї органам.

Теократичне правління малаЮдея V-I ст. до н. е., де влада була зосереджена в руках жерців на чолі 3 юдейським першоієрархом; Папська область в Італії у 756 - 1870 рр., а з 1929 р. - держава-місто Ватикан, де Папа Римський єабсолютним монархом, що зосередив у своїх руках необмежену політичну і духовну владу. Теократія поширена в мусульманських країнах (в Ірані, Саудівській Аравії тощо), де дотримуються традицій, що сформувалися ще в Дамаському халіфаті за династії Омеядів (661-750), Абасидів (750-1258).

2. Цезаропапізм (лат. caesar - цезар, рара - папа) - Церква та її структури повністю залежать від світської влади. Цезаропапське правління було у Візантії, де імператори не лише призначали чи звільняли патріархів, митрополитів, а й вирішували питання організаційного, канонічного і навіть догматичного розвитку церкви; Московія (пізніше Росія), де з XVIII до початку XX ст. главою Православної Церкви був імператор (цар).

3. Державна церква - забезпечується в державі привілейований стан певній конфесії. Передбачається пряме фрінансування державою іiї інституцій і державний контроль за використанням коштів, делегування церковним структурам певних державних фрункцій (реєстрація новонароджених, смертей, шлюбів тощо). Прикладом такої моделі державно-церковних взаємин є Греція, де державною $є$ Православна Церква, статут якої має статус державного закону. Держава гарантує священнослужителям Церкви зарплату і пенсії. У початкових і середніх школах ведеться православна освіта. Схожою до грецької є сучасна італійська модель державно-церковних відносин, де більше 90 відсотків громадян охрещені в католицькій Церкві. Відмінні фрорми державної церкви існують також у Великобританії, Данії, Швеції та інших країнах. Особливий статус певної церкви зафріксовано у конституціях понад 40 держав світу. У 22 із них главою держави може бути лише людина, що належить до офіційної Церкви.

4. Відокремлення церкви від держави - унеможливлюється будь-яке втручання Церкви у справи держави при активному втручанні державних інституцій у справи Церкви.

Таку модель відносин ілюструють колишні країни "соціалістичного табору", передусім колишній Радянський Союз, законодавча база яких теоретично гарантувала свободу совісті, однак у конкретному житті віруючі розглядалися як політичні вороги, а відтак зазнавали різноманітних пригнічень і дискримінації.

5. Відокремлення Церкви і держави - невтручання держави у справи Церкви, а Церкви - у справи держави, що забезпечує максимальну свободу релігії та ре- 
жим толерантності. Типовим прикладом цієї моделі державно-церковних взаємин є США, де конституція проголошує свободу для релігійних інституцій, їх незалежність від світського контролю чи маніпуляції властей. Основний меседж цього документу такий - неприпустимо примушувати чи спонукати будь-кого проти власної волі відвідувати або не відвідувати церкву, сповідувати чи не сповідувати певну релігію. Ніяка особа не може бути покарана за свою релігійну віру чи безвір'я, за відвідування чи невідвідування церкви. Жоден уряд, жодна адміністративна структура не можуть визначати мету діяльності Церкви, призначати її керівників або вказувати, як їй належить вести свої справи. Схожу, законодавчо закріплену, свободу вірити або не вірити мають громадяни Франції, Туреччини, України та інших країн.

Саме формулювання "відокремлення Церкви і держави" базується на тому, що держава не втручається у справи Церкви, а Церква - у справи держави.

6. Поєднання моделі державної Церкви і моделі повного відокремлення Церкви і держави - передбачає збереження певних видів державної підтримки та привілеїв окремих церков. Прикладом цієї моделі $€$ Німеччина, де, проголошено нейтральність і толерантність держави до різних конфесій, та все ж залежно від кількості прихильників зберігаються певні відмінності у ставленні до релігійних організацій. Якщо прибічників певної конфесії більше одного відсотка від загальної кількості населення певної землі Німеччини, то вони отримують спеціальний статус, який дає їм змогу, наприклад, отримувати державні дотації на власні школи, дитячі садки. Нині в цій країні нараховується 15 конфесій зі спеціальним статусом. Подібні державно-церковні відносини склалися в Японії, Австрії, Перу та інших країнах світу.

Еволюція цих стосунків упродовж двох тисячоліть засвідчує, що вони постійно змінювалися, вдосконалювалася, або, навпаки, переростали в деспотизм та тиранію. Втім, найбільш вдалою фрормою цих стосунків $\epsilon$ конкордат (лат. concordatum - угода) - договір між папою римським як главою держави й Римсько-католицької церкви та іншою католицькою державою, який регулює правовий стан Римсько-католицької церкви в даній державі, а також відносини цієї держави зі святим престолом [7, с. 9, 11-12]. Договори з некатолицькими урядами називаються конвенціями. Але в 19 ст. через зміни політичної карти Європи чітка різниця між цими типами договорів зникла. Конкордат $є$ виявом взаємної поваги та суверенітету.

Всі інші підходи систематизації цих взаємин та взаємодії між цими суб'єктами не були такими ефективними, як очікувалося. Класично кваліфікація державноцерковних взаємин базується на такому розподілі: системи відокремлення, системи конкордату і системи національних церков. Ця потрійна класифікація частково перебільшувала суть стосунків між державою та церквою, спотворивши зміст і функціональні особливості, не створивши їх системних моделей.

Відтак наступним кроком у пізнанні природи державно-церковних відносин стала культурно-географічна модель, яка передбачає такі модифікації [8, с. 26-27]:
- європейську, згідно з якою є традиційні чи національні церкви дістають особливий статус: держава визнає їх виняткову роль і розробляє спеціальні заходи щодо їх підтримки або культивування;

- американську, при якій усі регіональні об'єднання без винятку отримують однаковий статус перед державою: всі різні - всі рівні. За цієї моделі дозволяється діяльність будь-якої релігії, навіть сатанистів або саєнтологів;

- радянську, яка окреслює необмежену вищість держави відносно Церкви, включення Церкви в ідеологічну систему держави. Втім, церкви були обмеженими у своїх правах та існували в дуже обмеженому правовому просторі, який виключає будь-яку соціальну функцію поза межами культу.

Щоб краще зрозуміти суть державно-церковних взаємин, необхідно розібратися в засадничих поняттях - чим $€$ держава та які її фрункції, чим є Церква та які її функції, яке їх місце в суспільстві, а також як право регламентує взаємини між ними.

Сучасна юриспруденція визначає Державу як організацію політичної влади у суспільстві, яка забезпечує його цілісність, функціонування та розвиток шляхом управління та координації інтересів різних соціальних груп [9, с. 21], є суверенним політичним утворенням 3 визначеною територією, господарством і політичною владою.

Церква $є$ предметом віри в Господа, а тому сприяє прогресу в суспільстві через гармонійний вплив на людину. Христова Церква є спільнотою, яка об'єднує людей духовно, скеровує їх та регулює їхню поведінку десятьма Божими заповідями. Заснована Ісусом Христом, ця спільнота вірних, хоч і не має визначеної території, однак володіє всіма повноваженнями [10, с. 75-76], що необхідні їй для виконання її основного завдання: спасіння свого ковчегу, ввірених їй душ [11, кан. 595, § 2].

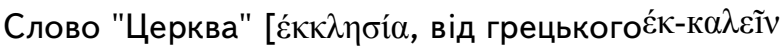
- "викликати"] означає "скликання" [12, с. 73]. На початках це були народні збори релігійного характеру (Пор. Ді. 19,39.), згодом це слово почало також застосовуватися у вже відомому нам контексті (спеціальні приміщення для відправлення Божественної Літургії, інших богослужень, а також зібрань вірян). Унікальність Церкви полягає у тому, що "вона одночасно $є$ людською і Божою [12, с. 73].

Об'єднуючим чинником інституцій (держави і церкви), його основним та первинним суб'єктом є людина. За будь-яких обставин людина $є$ одночасно членом i складовою як Церкви, так і суспільства, так і держави. Ці інституції створені тільки для блага людини, але не навпаки.

Посилаючись на загальне світорозуміння, уявлення про закономірності існування природи і суспільства, право виступає для упорядкування відносин у суспільстві, зокрема для регулювання стосунків між Церквою та державою [13, с. 249].

$€$ різні підходи щодо розуміння походження права, щонайбільше: природно-правовий - джерелом $є$ Бог і Його абсолютні та вічні закони; позитивний - право створюється державою. 
Право - це система норм і правил, які встановлюються і забезпечуються державою з метою врегулювання суспільних відносин. Загалом право - це раціональний, стабільний і примусовий порядок людських дій в матерії соціальної справедливості [14, с. 7]. Правовими нормами є правила, які встановлені і забезпечені компетентною владою (державою, Церквою та ін.), більшість з яких мають імперативний характер. Людину як суспільну істоту спонукує до творення певних норм поведінки розуміння справедливості, правди, свободи тощо. Право може базується на звичаях, які відштовхуються від об'єктивних обставин і моральних засад. Втім, право лише юридично закріплює мораль, але її не створює.

Мораль формує світогляд (онтологічний, гносеологічний, практичний, аксіологічний) людини, який виражається в системі моральних цінностей, котрі $€$ основою правотворення.

Моральна уява чи реалізація знаходиться в індивідуальних цінностях людської особи, створюючи певну ієрархію, яка може бути спрямована до добра, а також і до зла, що в результаті впливає на свідомість, відтак на мораль та правотворення.

Церква позитивно структурує особистість людини, налаштовує її на оптимальне вирішення важливих життєвих питань та виховуює у ній людську гідність, яка $є$ найважливішим атрибутом людини, особливим морально-етичним стрижнем. Усвідомлення людиною її походження від небесного Отця піднімає людську особу на якісно інший рівень свідомості.

Існування цінностей пов'язане з мірилом чи критерієм оцінки (ідеєю добра людини, яке є тривалим змістовним пошуком людини. Моральним $є$ те, що є добрим. Філософрія налічує багато підходів щодо цього: гедоністичний, утилітаристичний, евдемоністичний, еволюціоністський, метафізичний та ін. з позиції Церкви Бог не залишає людину з її моральними проблемами та потребами. Моральний закон є ділом Божої Мудрості, який приписує розумний порядок, установлений між творіннями силою, мудрістю і добротою Творця для їхнього добра і з огляду на їхню мету [15, с. 454-455]. Ісус Христос проголошує Небесне Царство, яке за своєю суттю є спасінням людини та її найбільшим благом, а Бог, Його заповіді та благодать (любов) $є$ найбільшими цінностями. Таким чином Церква визнає моральне життя духовним культом [16, с. 391]. Тут ідеться про вільний вибір людини щодо вибору цінностей та віровизнання.

Якість права, як засобу врегулювання суспільних стосунків, пов'язана з рівнем моральності суспільства, який залежить від формування світоглядної ієрархії цінностей конкретних людей, які складають це суспільство.

Ще однією проблемою $є$ те, що сучасне цивільне право дає індивідууму свободу на різних рівнях. Але Бог створив людину соціальною за природою, тому необхідно, щоб держава, випливаючи з факту буття суспільства, визнала і поважала Бога як Автора. Тому розумом і тверезим глуздом засуджується атеїстична держава. Індиферентне та однакове ставлення державою до всіх релігій та культів $є$ наслідком розриву (відокремлення) між державою та Церквою. Не можна плутати забезпечення державою однакових та рівних прав усіх релігійних організацій в суспільстві із ставленням держави до Церкви. Ставлення $€$ особистісною категорією, яка характеризується свободою вибору, тому держава має повне право виражати прихильне ставлення до Христової Церкви, виражаючи волю народу, не порушуючи при тому права на існування інших релігійних організацій.

Реалізація правових норм у суспільстві переважно забезпечується державними правоохоронними та контролюючими органами шляхом примусу та різних видів покарань за їх порушення. Основною складовою цих державних органів $€$ конкретні люди із власними мораллю, світоглядом та ієрархією цінностей. Ці органи не завжди не тільки не виконують свої завдання та функції, а й порушують правові норми та вимоги, що призводить до таких ганебних явищ як корупція, несправеливість, зубожіння людей, руйнація економіки і морального клімату суспільства тощо. Рівень дії приписів моральних та юридичних норм в суспільстві залежить від рівня підкорення волі людини цим вимогам. Таке підкорення можливе завдяки вірі, яка полягає у добровільному переконанні у тому, що Боже Слово, яке дається Господом через Церкву і в Церкві, $є$ найбільшим добром. Це Слово, Його Дух починає жити в людині. Божий страх, боязнь образити Того, хто її найбільше любить, створюють внутрішній імператив, який $є$ внутрішнім обов'язком людської особи, де вона себе примушує, що цілком сумісно з її внутрішньою свободою [17, с. 32], оскільки вона сама робить такий вибір. Це сприяє власному і загальному добру.

Сьогодні правовий режим і статус Церкви та інших громадських релігійних об'єднань, свободи совісті та віросповідання, ставлення держави до Бога і Його Церкви регламентовано Конституцією України, прийнятою на п'ятій сесії Верховної Ради України 28 червня 1996 року та Законом України "Про свободу совісті та релігійні організації", введеним в дію Постановою Верховної Ради України № 988-ХІІ від 23 квітня 1991.

У преамбулі Основного Закону говориться: "Верховна Рада України від імені українського народу громадян України всіх національностей,... усвідомлюючи відповідальність перед Богом, власною совістю, попередніми, нинішнім та прийдешніми поколіннями,... приймає цю Конституцію - Основний Закон України" [18]. Верховна Рада України, яка є найвищим представницьким органом влади у нашій державі від імені народу та виражаючи його волю, усвідомлює відповідальність перед Богом за прийняття найважливішого правового документа, тим самим визнає найбільший авторитет Того, перед ким така відповідальність $€$ усвідомленою, тобто одного конкретного Бога, в Якого вірить наш народ. Цим словосполученням виражено позицію держави, а відповідно більшості її громадян щодо віровизнання. Як зазначив Гавдьо, за таких обставин в Основному Законі України варто було б визначити позицію та ідентифікацію нашої держави щодо християнської релігії, яку сповідує переважна більшість іï громадян (згідно із статистикою. 87,8 \%) [19]. Відповідно Україна мала б бути християнською.

Статтею 35 Конституції України виражено позицію держави щодо релігій та Церкви, в якій передбачено, що кожен має право на свободу світогляду і віроспові- 
дання.... Церква і релігійні організації в Україні відокремлені від держави, а школа - від церкви.... [20].

Будівництво демократичного суспільства $є$ неможливим без свободи совісті. Новітній державі Україна важливо напрацювати реальні кроки в напрямі удосконалення конституційних та законних засад свободи совісті. В Конституції мова йде про Церкву в однині, а оскільки переважна більшість нашого народу, який $є$ єдиним носієм влади (ст. 5 Конституції України) є християнами, то можна з певністю сказати, що мова йде про Церкву християн.

Слово "відокремлювати" означає роз'єднувати, розділяти, відгороджувати, переривати зв'язок або зв'язки з чимось (з кимось), відриватися від чогось, віддалятися чи відходити від когось чи чогось [21, с. 14]. 3 огляду на преамбулу Конституції, історію українського народу та реалії, то з певністю можна сказати, що Церква не $\epsilon$ відірваною від народу та держави, а, навпаки, іiї діяльність та й вона сама пов'язана тісними зв'язками як з народом, так і з державою, яка його уособлює. Це було продемонстровано підчас революції Гідності на Майдані Незалежності у Києві. Тому логічним та влучним було б сорормулювати цю частину положень Конституції в такій редакції, що "Церква, релігійні організації та держава в Україні є самостійними і незалежними особами (інституціями), які діють у суспільстві та за його межами самостійно, також взаємодіють між собою у відповідності до своїх завдань і призначення, а також законодавства України і міжнародно-правових норм та правил. Стосунки між державою та Церквою будуються на принципі взаємодопомоги та взаємоповаги. Держава не $є$ перешкодою для впровадження в школу богословських наук Церкви на взаємних у кожному випадку добровільних началах" [22].

Більшість вчених вважає, що концепція відокремлення Церкви від держави вперше була проголошена Білль про права США (неофіційна назва перших десяти поправок до Конституції США, які закріплюють основні права людини), ратифрікованою Конгресом США в 1791 р. Зокрема в першій поправці до конституції цієї держави зазначено: "Конгрес не повинен ухвалювати законів, що запроваджували б будь-яку релігію чи забороняли б вільне відправлення релігійних обрядів...". Немає тут жодного слова про відокремлення Церкви від держави, мова йде лише про невтручання держави у свободу віросповідування. Насправді ж причиною такого тлумачення першої поправкиє приховане вороже ставлення до будь-якої релігії [22].

Держава і Церква, маючи своє право, повинні дотримуватися їх засад, розвиваючи між собою стосунки при умові взаємоповаги суверенності цих суб'єктів.

Церква, на відміну від держави, не має визначеної території і місцезнаходження ії членів та діяльність виходять за межі держави, $є$ рівним партнером з державою, $є$ самостійною незалежною інституцію, яка творить свої закони і правила. Вона підпадає під юрисдикцію національного права у випадку територіального розміщення її органів, майна, членів та організацій, які мають дотримуватися його вимог. Національне законодавство повинно забезпечувати правові умови діяльності Церкви та її організацій без порушення прав інших релігійних організацій. Необхідно створити правовий ме- ханізм взаємних і партнерських стосунків, який має передбачити визнання державою Церкви як особливого незалежного і самостійного суб'єкта з відповідними юридичними наслідками.

Відповідно до частини 2 статті 2 Цивільного Кодексу України держава є учасником цивільних відносин, проте чинним законодавством України не передбачено, що держава $є$ юридичною особою. Статус юридичної особи публічного права вона реалізує через свої органи, підприємства та організації, які її уособлюють та представляють [23, с. 104]. Очевидно, такого ж статусу слід домагатися і Церкві [24].

В ідеалі взаємні стосунки між державою та Церквою мають будуватися на відповідному договорі, що вводить Церкву в міжнародний простір як суб'єкта міжнародного права, тобто учасників міжнародних правовідносин, яким притаманні елементи міжнародної правосуб'єктності, тобто вони здатні володіти та безпосередньо здійснювати міжнародні права й обов'язки, створювати норми міжнародного права та нести відповідальність заїхнє порушення та ін.

Статус суб'єкта міжнародних відносин встановлюється шляхом визнання його існуючими суб'єктами міжнародних відносин. Тому Церква, з врахуванням іiї специоріки, має вживати достатньо заходів для набуття статусу суб'єкта міжнародних відносин та розуміння цієї позиції всіх Церков.

Часто в міжнародному праві використовується термін "дестинатор міжнародного права", який означає особу, яка не володіє усіма елементами міжнародної правосуб'єктності, але може брати участь в окремих правовідносинах, урегульованих нормами міжнародного права. Проте така участь не $є$ безпосередньою, а опосередковується яким-небудь іншим суб'єктом міжнародного права (державою), хоча, як виняток, можлива іiї безпосередня участь. Дестинаторський підхід можливо застосувати щодо східніх Церков.

До основного єдиного виду договору між державою та Церквою відноситься конкордат (двостороння угода), який укладається зі Святим Престолом. Договірноправова база Ватикану розвинулася після II Ватиканського собору, який відкрив нові можливості для розвитку міжнародного співробітництва Святого Престолу, після якого було підписано близько 120 конкордатів 3 низкою країн Європи, Латинської Америки, Азії, Афррики та ісламських держав. Сьогодні в світі нараховується біля 160 конкордтів.

Сьогоднішнє право, яке визначає статус Церкви у нашій державі, на жаль, не передбачає можливості укладення такої міжнародної угоди нашої держави з Апостольською Столицею. Однак відсутність правого дозволу на такі конкордати не означає, що вони не можуть бути укладеними, оскільки за конституційним принципом дозволено те, що не заборонено законом [25, ст. 19]. Проте сьогоднішнє національне законодавство суттєво обмежило б зміст самого конкордату. Органи публічного управління мають ініціювати про внесення змін та доповнень у законодавство на користь укладення такої угоди.

Зміст конкордатів здебільшого складають права Церкви з питань гарантування релігійної свободи, свободи Церкви, прав віруючих, діяльності церковних ус- 
танов, шлюбно-сімейних відносин, освіти, сплати податків, певних економічних привілеїв, фрінансування виконання завдань Церкви, церковних приміщень. Їх предметом $€$ досягнення балансу церковних та державних інтересів правовою основою врегулювання спорів між державою та Церквою, налагодження та розширення співпраці з світською владою та ін. [26, с. 23]. Святий Престол, використовуючи, оновляючи та розширюючи свою міжнародно-правову базу, здійснює гнучку і динамічну політику, регулює проблемні питання у взаєминах з державами світу, зміцнює довіру і взаєморозуміння, захищає свободу віросповідання, релігійні права мирян та інтереси Католицької Церкви в цілому [26, с. 23].

У випадку підписання Конкордату з Україною та ратифрікації Верховною Радою України відповідно до ст. 9 Конституції України він може стати частиною національного законодавства нашої держави і ця обставина вводить його в область права як регулятора суспільних відносин [27, ст. 9].

Держава також може запропонувати інші варіанти договорів, як наприклад, з Православними Церквами.

Мир у суспільстві, злагода і добробут нації напряму залежать від того, яким є морально-етичний стрижень народу, якими є його цілі, його ставлення до слабких, безборонних, до дару Життя. Головним державотворчим заданням на сьогодні $€$ навернути суспільство до високих морально-етичних стандартів, які викладено у християнстві, що також дасть його оздоровлення на всіх рівнях.

\section{ВИСНОВКИ}

Пропоноване дослідження обгрунтовує необхідність інтегрування публічними управлінцями християнських цінностей і засад у наше суспільство з допомогою не тільки Церкви, а й держави (школа, наука, матеріальні та інші блага).

Органам публічного управління варто визнати нашу державу християнською, упорядкувати церковно-державні стосунки шляхом визнання державою Церкви як незалежного, самостійного та морального авторитета суспільства на законодавчому рівні та привести вимоги чинного законодавства України до християнсько-моральних засад.

Публічним управлінцям необхідно доповнити визначення чинної статті 1 Конституції України, додавши у її фрормулювання "Україна є християнська держава"; а також внести до чинної статті 35 Конституції України корективи: "Церква (церкви) і держава в Україні $€$ суспільними, незалежними, самостійними інституціями, які спільно кожна в свій спосіб та призначення дбають про добробут своїх вірних та громадян. Між державою та церквою можуть укладатися відповідні угоди на засадах партнерства, взаємодопомоги, взаємоповаги і толерантності. Держава визнає Церкву суб'єктом правових відносин зі спеціальним соціальним статусом, який визначається законодавством України або договором та не перешкоджає впровадженню у школі релігійних наук на добровільних засадах. Церква є духовним і моральним авторитетом у суспільстві".

Перспективи подальших досліджень полягають у розробці механізмів впровадження християнських мо- рально-етичних цінностей в процеси державотворення.

Література:

1. Мондін Баттіста. Підручники системної фрілоcoфiї: Том 6. Етика і політика. [підручник]. Жовква: Місіонер, 2017. 248 c.

2. Томос для України отримав всі необхідні підписи (09.01.2019 p.). URL: https://www.radiosvoboda.org/ a/news-tomos-ukrayina-pidpysy/29699352.html (дата звернення: 09.10.2019р.).

3. Мондін Баттіста. Підручники системної фрілософрії: Том 6. Етика і політика. [підручник]. Жовква: Місіонер, 2017. 248 c.

4. Concilio Vaticano II. Gaudium et Spes: Costituzione Pastorale, 7 dicembre 1965. Citta del Vaticano: Libreria Editrice Vaticana, 1965. 64 p.

5. Мондін Баттіста. Підручники системної фрілософрії: Том 6. Етика і політика. [підручник]. Жовква: Місіонер, 2017. 248 с.

6. Черній А.М. Релігієзнавство. [посібник]. Київ: Академвидав, 2003. с. 352.

7. Martin De Agar, I concordati del 2000, Libreria Editrice Vaticana, 2001. P. 9, 11,12, 80 p.

8. Рибачук М. Моделі державно-церковних відносин в Україні в контексті державотворчого процесу [матеріали міжнародної наукової конференції Україна - Ватикан: державно-церковні відносини в контексті досвіду об'єднаної Європи]. Галич: Давній Галич, 2011. С. 26-27.

9. Луць Л.А. Загальна теорія держави та права: [навч.-метод. посіб. (за кредитно-модульною системою)]. Київ: Атіка, 2012. 411 с.

10. Ліберо Джероза. Церковне право. Львів: Свічадо, 2001. С. 33.

11. Кодекс Канонів Східних Церков. Рим: Вид-во отців василіян, 1993. 1546 кан.

12. Катехизм католицької церкви. [Синод Української Греко-Католицької Церкви]. Жовква: Місіонер, 2002. $772 \mathrm{c}$.

13. Зайчук О.В., Оніщенко Н.М. Теорія держави і права. Київ: Юрінком Інтер, 2006. 688 с.

14. Мудрий Софрон, Публічне право Церкви і конкордати, Жовква: Місіонер, 2011. 192 с.

15. Катехизм католицької церкви. [Синод Української Греко-Католицької Церкви]. Жовква: Місіонер, 2002. $772 \mathrm{c}$.

16. Загальна теорія держави і права / За редакцією М.В. Цвіка, В.Д. Ткаченка, О.В. Петришина. Харків: Право 2002. 432 c.

17. Сливка С.С. Юридична деонтологія: підручник. Київ: Атіка, 2012. 296 с.

18. Конституція України: Закон від 28.06.1996 №254к / 96-ВР. База даних "Законодавство України" /BP України. URL: http//zakon2.rada.gov.ua/laws/ show (дата звернення: 09.10.2019).

19. Релігія в Україні (2019). URL: http//uk.wikipedia.org/wiki/Релігія в Україні (дата звернення: 09.10.2019 p.).

20. Конституція України: Закон від 28.06.1996 № 254к / 96-ВР. База даних "Законодавство України" / BP України. URL: http//zakon2.rada.gov.ua/laws/ show (дата звернення: 09.10.2019). 
21. Дубічинський В.В. та ін. Сучасний тлумачний словник української мови. Харків: Школа. 2008.784 с.

22. Гавдьо Б. Право як засіб врегулювання державно-церковних стосунків URL: https://www.academia.edu /7193832/(дата звернення: 09.10.2019р.).

23. Цивільний кодекс України: Науково-практичний коментар: У 2 ч. / За заг. ред. Я.М. Шевченка. Київ: Ін Юре, 2004. - Ч. 1 / [Бабаскін А.Ю., Безклубий І.А., Безсмертна Н.В. та ін.]. 689с.; Ч. 2 / [Бабаскін А.Ю., Безклубий І.А., Безсмертна Н.В. та ін.]. 896с.

24. Гавдьо Б. Право як засіб врегулювання державно-церковних стосунків URL: https://www.academia.edu /7193832/(дата звернення: 09.10.2019р.).

25. Конституція України: Закон від 28.06.1996 №254к / 96-ВР. База даних "Законодавство України" /BP України. URL: http//zakon2.rada.gov.ua/laws/ show (дата звернення: 09.10.2019).

26. Хорунжій Г. Конкордати, як міжнародно-правові угоди Святого Престолу [Матеріали V міжнародної наукової конференції. Україна - Ватикан: державно-церковні відносини в контексті досвіду об'єднаної Європи]. Галич: Давній Галич", 2011, с. 452

27. Конституція України: Закон від 28.06.1996 №254к / 96-ВР. База даних "Законодавство України" /BP України. URL: http//zakon2.rada.gov.ua/laws/ show (дата звернення: 09.10.2019).

\section{References:}

1. Mondin, B. (2017), Pidruchnyky systemnoi filosofii: Tom 6 [System Philosophy Textbooks: Volume 6. Ethics and politics], Press Misioner, Zhovkva, Ukraine.

2. https://www.radiosvoboda.org/a/news-tomosukrayina-pidpysy/29699352.html (Accessed: 09 Dec 2019).

3. Mondin, B. (2017), Pidruchnyky systemnoi filosofii: Tom 6 [System Philosophy Textbooks: Volume 6. Ethics and politics], Press Misioner, Zhovkva, Ukraine.

4. Concilio Vaticano II (1965), Gaudium et Spes: Costituzione Pastorale, Libreria Editrice Vaticana, Citta del Vaticano, Vaticano.

5. Mondin, B. (2017), Pidruchnyky systemnoi filosofii: Tom 6 [System Philosophy Textbooks: Volume 6. Ethics and politics], Press Misioner, Zhovkva, Ukraine.

6. Chernii, A.M.(2003), Relihiieznavstvo [Religious studies], Press Akademvydav, Kyiv, Ukraine.

7. De Agar, M. (2001), I concordati del 2000, Libreria Editrice Vaticana, Citta del Vaticano, Vaticano.

8. Rybachuk, M. (2011), "Models of State-Church Relations in Ukraine in the Context of the State-Making Process", Materialy mizhnarodnoi naukovoi konferentsii Ukraina - Vatykan: derzhavno-tserkovni vidnosyny $v$ konteksti dosvidu obiednanoi Yevropy] [Proceedings of the International Scientific Conference Ukraine-Vatican: State-Church Relations in the Context of the United Europe Experience], Press Davnii Halych, Halych, Ukraine.

9. Luts, L. A. (2012), Zahalna teoriia derzhavy ta prava: navch.-metod. posib. (za kredytno-modulnoiu systemoiu) [General theory of state and law: teaching-method. tool. (on credit-modular system)], Press Atika, Kyiv, Ukraine.

10. Dzheroza, L. (2001), Tserkovne pravo [Church law], Press Svichado, Lviv, Ukraine.
11. Vasylian (1993), Kodeks Kanoniv Skhidnykh Tserkov [Code of Canons of the Eastern Churches], House of the Basilian Fathers, Rome, Italy.

12. Synod Ukrainskoi Hreko-Katolytskoi Tserkvy (2002), Katekhyzm katolytskoi tserkvy [Catechism of the Catholic Church], Press Misioner, Zhovkva, Ukraine.

13. Zaichuk, O. V. and Onishchenko, N. M. (2006), Teoriia derzhavy i prava [Theory of state and law], Press Yurinkom Inter, Kyiv, Ukraine.

14. Mudryi Sofron (2011), Publichne pravo Tserkvy i konkordaty [Church Public Law and Concordat], Press Misioner, Zhovkva, Ukraine.

15. Synod Ukrainskoi Hreko-Katolytskoi Tserkvy (2002), Katekhyzm katolytskoi tserkvy [Catechism of the Catholic Church], Press Misioner, Zhovkva, Ukraine.

16. Tsvik, V M. Tkachenko, V. D. and Petryshyn, O. V. (2002), Zahalna teoriia derzhavy i prava [General theory of state and law], Press Pravo, Kharkiv, Ukraine.

17. Slyvka, S. S. (2012). Yurydychna deontolohiia [Legal deontology], Press Atika, Kyiv, Ukraine.

18. Verkhovna Rada of Ukraine (1996), "The Constitution of Ukraine", available at: http://zakon5.rada.gov.ua/laws/show/en /254\%D0\%BA/96-\%D0\%B2\%D1\%80 (Accessed 09 Dec 2019).

19. wikipedia (2019), "Religion in Ukraine", available at: http//uk.wikipedia.org/wiki/Relihiia v Ukraini (Accessed 09 Dec 2019.).

20. Verkhovna Rada of Ukraine (1996), "The Constitution of Ukraine", available at: http://zakon5.rada.gov.ua/laws/show/en /254\%D0\%BA/96-\%D0\%B2\%D1\% 80 (Accessed 09 Dec 2019).

21. Dubichynskyi, V.V. (2008), Suchasnyi tlumachnyi slovnyk ukrainskoi movy. [Modern Ukrainian Dictionary of Interpretation], Press Shkola, Kharkiv, Ukraine.

22. Gavdio, B. (2019), "Law as a Means of Settlement of State-Church Relations", available at: https://www.academia.edu /7193832/(Accessed: 09 Dec 2019).

23. Shevchenko, Ya.M. (2004), Tsyvilnyi kodeks Ukrainy: Naukovo-praktychnyi komentar [Civil Code of Ukraine: Scientific and Practical Commentary], Press In Yure, Kyiv. Ukraine.

24. Gavdio, B. (2019), "Law as a Means of Settlement of State-Church Relations", available at: https:// www.academia.edu/7193832/(Accessed: 09 Dec 2019).

25. Verkhovna Rada of Ukraine (1996), "The Constitution of Ukraine", available at: http://zakon5.rada.gov.ua/laws/show/en /254\%D0\%BA/96-\%D0\%B2\%D1\%80 (Accessed 09 Dec 2019).

26. Khorunzhii, H. (2011), "Concordats as international legal agreements of the Holy See", Materialy V mizhnarodnoi naukovoi konferentsii. Ukraina - Vatykan: derzhavno-tserkovni vidnosyny $v$ konteksti dosvidu obiednanoi Yevropy [Proceedings of the 5th International Scientific Conference. Ukraine-Vatican: Church-State Relations in the Context of the United Europe Experience], Press Davnii Halych, Halych, Ukraine.

27. Verkhovna Rada of Ukraine (1996), "The Constitution of Ukraine", available at: http://zakon5.rada.gov.ua/laws/show/en /254\%D0\%BA/96-\%D0\%B2\%D1\%80 (Accessed 09 Dec 2019).

Стаття надійшла до редакчї 10.01.2020 p. 